\title{
Stents in Gastrointestinal Endoscopy
}

\author{
Michael Pavlides and David A Gorard \\ Wycombe Hospital, High Wycombe, \\ United Kingdom
}

\section{Introduction}

Advanced endoscopy can be used to insert stents (hollow tubes) into various sites of the gastrointestinal tract and this has proved to be a major therapeutic advance. Stents can hold open strictured areas in the oesophagus, the biliary tree, the colon and the gastroduodenal region. Stents are usually positioned in order to overcome stricturing associated with cancerous tumours. They are used as definitive treatment, as a bridge to surgery, and for palliation of obstructive symptoms. In the setting of incurable gastrointestinal cancer, the endoscopic placement of such stents allows palliation of symptoms non-invasively, and is an attractive alternative to surgery. Stents can also be used in benign disease of the gastrointestinal tract.

The basic principles of stent insertion involve the initial placement of a guidewire, (and sometimes an overrunning introducing catheter) across the region to be stented, using endoscopic vision and often fluoroscopic guidance too. The stent is advanced over the guidewire until it traverses the area to be stented. In the case of self-expanding stents, the restraining mechanism is then released to deploy the stent.

Gastrointestinal stent insertion is not the sole domain of the endoscopist. Gastrointestinal stents are also placed non-endoscopically by radiologists. For example, interventional radiologists use fluoroscopic guidance to position oesophageal stents in the oesophagus, or can use a combination of sonography and percutaneous transhepatic cholangiography to place biliary stents in the biliary tree. The route of stent insertion may be influenced by local expertise, but the indications for stent insertion are usually those benefitting from a multidisciplinary approach involving endoscopists, surgeons, interventional radiologists and oncologists. Gastrointestinal stent insertion is an area of medicine where the territorial boundaries of interventional endoscopists, minimally invasive surgeons and interventional radiologists are increasingly blurred.

\section{Technology of stents}

\subsection{Simple plastic stents}

Initially endoscopic stents were solely plastic. Up until the 1990s, rigid plastic stents were used to stent stricturing oesophageal cancers. However the development of safer SelfExpanding Metal Stents (SEMS) has rendered these rigid plastic oesophageal stents obsolete. Today plastic stents are mainly confined to use in the biliary tree and pancreas. These plastic stents are usually composed of one of three polymers - polyethylene, polyurethane or Teflon. Plastic stents used in the biliary tree and pancreas may be straight with anchoring 
side-flaps to prevent migration. Alternatively, pigtailed stents may be used in the biliary tree. The curled end of a pigtail stent is straightened over the guidewire during positioning and the pigtail resumes its shape once the guidewire has been removed. The pigtail anchors the stent in position. The diameter of a plastic stent is usually described in terms of the French scale, where 1 French (Fr) is $0.33 \mathrm{~mm}$. Thus a 6 Fr stent has a diameter of $2 \mathrm{~mm}$. The maximum diameter of a simple plastic stent is limited by the maximum size of an endoscope's operating channel size at $12 \mathrm{Fr}$ or $4 \mathrm{~mm}$.

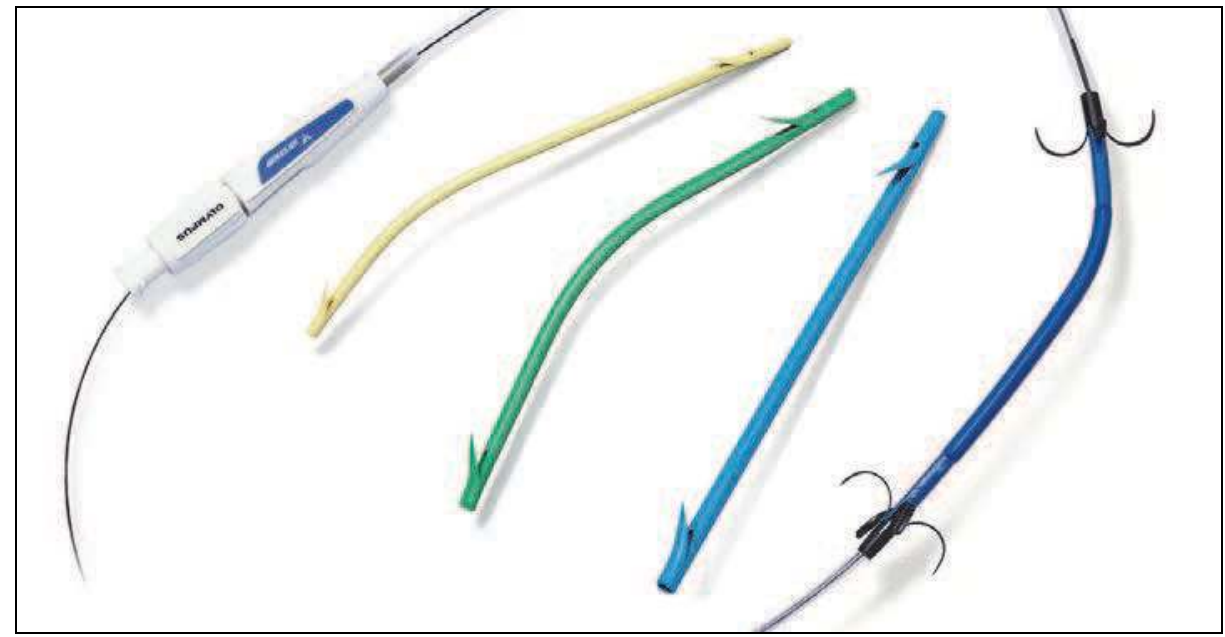

Fig. 1. Straight plastic stents used for biliary and pancreatic stenting

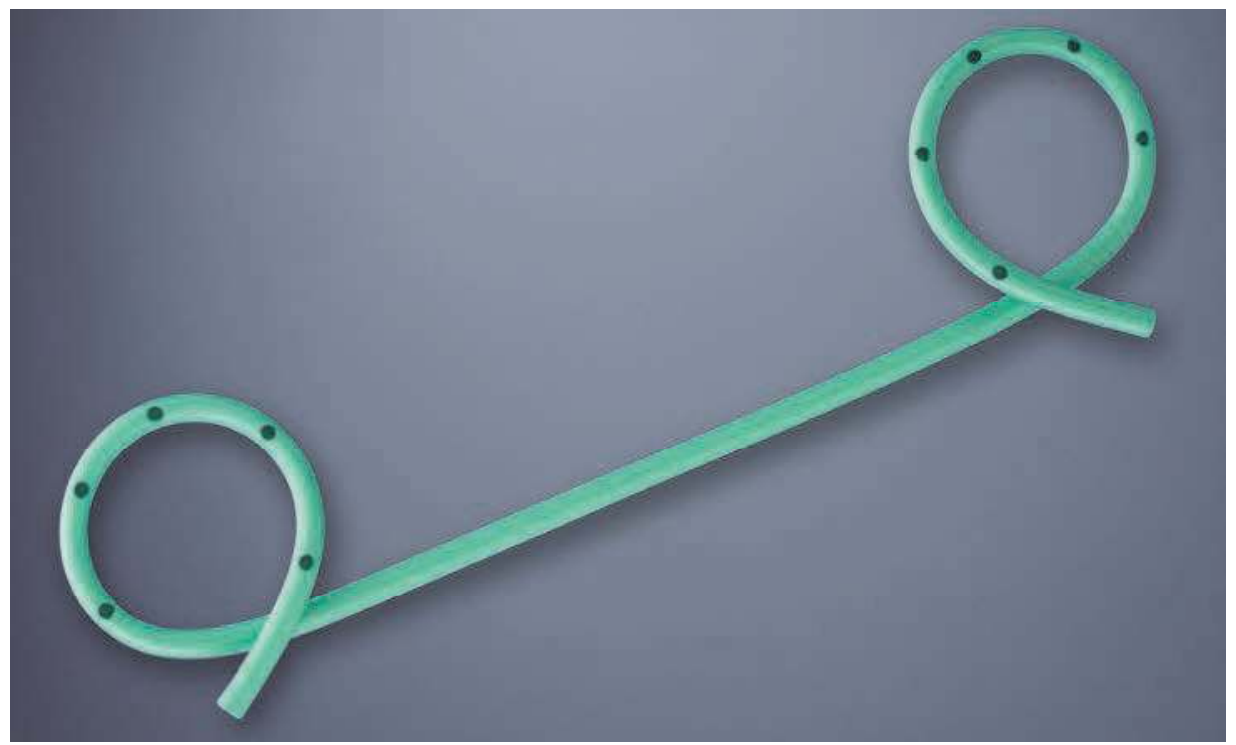

Fig. 2. Pigtail stent used for biliary stenting 


\subsection{Self-expanding stents}

Although simple plastic stents still have a role in biliary and pancreatic stenting, technological improvements have led to the development of smarter stents. Self-Expanding Metal Stents (SEMS) are positioned while collapsed, using a small calibre introducer. Insertion of SEMS is easier, safer, with a reduced risk of perforation, and much reduced need for prior stricture dilatation.

Metals in SEMS need to be biocompatible i.e. biologically innocuous when functioning in patients. Shape memory alloys are 'intelligent', possessing the ability to recover a previously defined length or shape when deployed in the patient (Tarnita et al., 2009). There are several types and sizes of SEMS on the market. Each has its own characteristics in terms of radial forces exerted, foreshortening on deployment, and flexibility. SEMS can be made from stainless steel e.g. Z-stent ${ }^{\circledR}$ (Cook Medical, Bloomington, IN, USA) or from alloys. Nitinol is an alloy of nickel and titanium used in Ultraflex ${ }^{\circledR}$ stent (Boston Scientific, Natick, MA, USA) and Alimaxx E® stent (Alveolus, Charlotte, NC, USA). Elgiloy, a cobalt / chromium / nickel alloy, is used in Wallstent ${ }^{\circledR}$ (Boston Scientific).

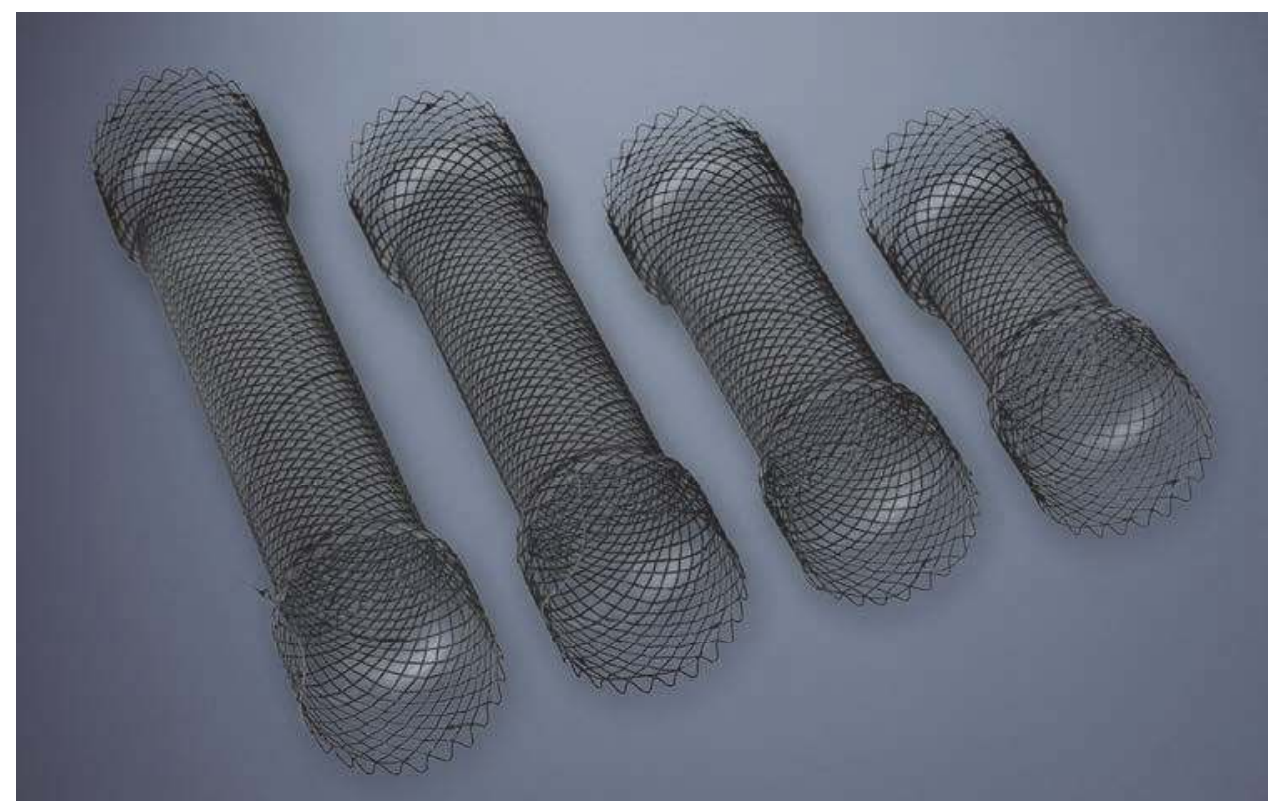

Fig. 3. Different sizes of Self-Expanding Metal Stents used in oesophageal stenting

SEMs should be fluoroscopically opaque to aid positioning, and should be easily deployable via a small calibre introducer. They are introduced in a collapsed position, being run over a guidewire positioned through the region to be stented. Once in position the constraining mechanism is released and the stent expands, exerting radial forces on any stricturing lesion thus increasing the lumen of the area being stented. SEMS are designed to expand to a diameter of more than $20 \mathrm{~mm}$. The bare metal strands of an uncovered stent may embed in the underlying tumour and serve to anchor the stent in position. Through pressure necrosis, the struts of the stent migrate into the mucosa and submucosa of the gut wall. A fibrous reaction with chronic lymphocytic infiltration occurs, as the stent becomes embedded in 
collagen and fibrous tissue. A chronic lymphocytic reaction occurs in the normal tissue underlying the proximal and distal ends of the stent (Bethge et al.,1996). Once in situ the stent should be MRI compatible.

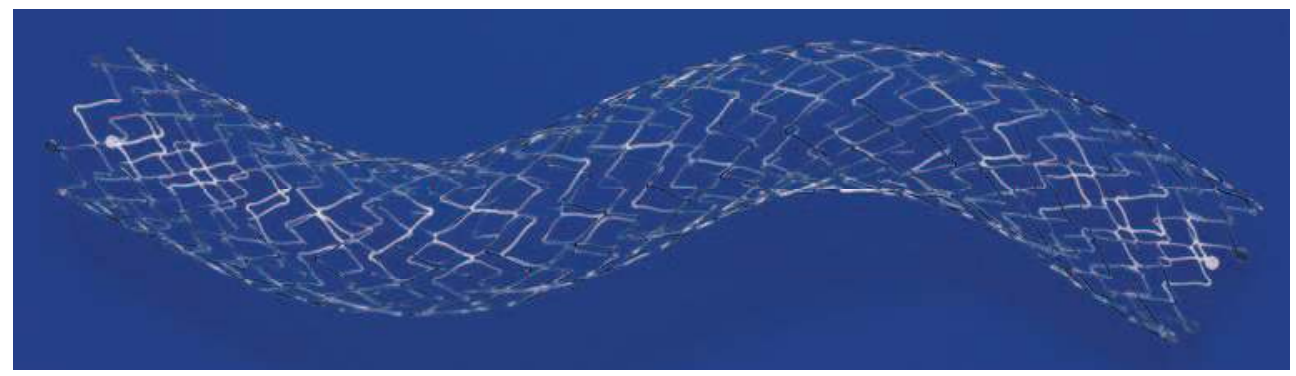

Fig. 4. Uncovered Self-Expanding Metal Stent used in biliary stenting

SEMS may be covered with a silicone membrane to reduce the risk of tumour in-growth and to seal fistulas. However fully covered stents are less likely to embed in the underlying tissues, and have an increased risk of stent migration compared to uncovered stents. Therefore, partially covered stents have been developed with flared uncovered segments at both ends to anchor on to the tissue. Fully covered SEMS are also increasingly used in benign oesophageal disease, such as non-malignant strictures and anastomotic leaks. The Polyflex ${ }^{\circledR}$ stent (Boston Scientific, Natick, MA, USA) is a removable self-expanding plastic stent for use in the management of benign and malignant oesophageal strictures. Such a removable self-expanding plastic stent allows temporary stent insertion for benign oesophageal disease and for patients undergoing neoadjuvant chemotherapy prior to oesophagectomy. Recently biodegradable stents have been developed which slowly break down over time, e.g. the SX-Ella Esophageal Degradable BD stent $\AA_{\text {, }}$ (ELLA-CS, HradecKralove, Czech Republic) made from the biodegradable polymer poly-dioxanon, and the Tanaka-Marui stent (Marui Textile Machinery Co., Osaka, Japan) composed of biodegradable poly-L-lactic acid monofilaments.

Potential complications of SEMS insertion include perforation, tumour overgrowth or ingrowth, and stent migration. Newer stents are being developed with the aim of increasing technical and clinical success rates, while reducing complication rates. Other areas of development include radioactive or drug-eluting stents for malignant disease.

\section{Oesophageal stents for malignant oesophageal obstruction}

Patients with oesophageal cancer experience progressive dysphagia and weight loss. Radical surgery in the form of oesophagectomy offers the only chance of cure. Unfortunately, patients often present late with inoperable tumours, or are too frail to be considered for surgery which itself caries significant morbidity and mortality. Dysphagia is a distressing and unpleasant symptom. Relief of dysphagia, so that patients can swallow again, is very important in the treatment of oesophageal cancer. Oesophageal stents are an excellent option for the palliation of dysphagia. In contrast to other treatment modalities like endoscopic laser or brachytherapy, stents are widely available and are not restricted to specialised centres. They can be inserted under endoscopic or fluoroscopic guidance or a combination of both. They rapidly relieve dysphagia, and can be used in 
patients with advanced inoperable disease or in patients too frail to have chemotherapy or radiotherapy.

The first stents used in malignant dysphagia were rigid plastic stents. Placing such rigid stents, and the necessary prior stricture dilatation carried a substantial risk of perforation. SEMS were developed in the early 1990s. Their design allows them to be preloaded onto a delivery mechanism typically measuring $5-10 \mathrm{~mm}$ in diameter. Consequently little or no dilatation is needed prior to stent insertion. Oesophageal SEMS are deployed over a guidewire after delineating the margins of the stricture endoscopically. Although the stents are usually deployed under fluoroscopic guidance, increasingly many endoscopists deploy them under direct endoscopic vision with the endoscope positioned alongside the guidewire-stent assembly. The diameter of most fully deployed oesophageal SEMS varies between 16 and $24 \mathrm{~mm}$ and their length varies between 7 and $15 \mathrm{~cm}$. SEMS are usually partially or fully covered with a membrane to prevent tumour ingrowth through the metal mesh.

Early studies comparing traditional rigid plastic stents and SEMS demonstrated the superiority of the latter in several domains. Knyrim et al (1993) compared the two types of stents and showed SEMS and rigid plastic stents to be equivalent in their improvement of dysphagia, 30 day mortality and re-intervention rates. However, metal stents were associated with fewer complications, shorter hospitalisation after stent placement and superior cost effectiveness (Knyrim et al., 1993). Subsequent randomised studies and a retrospective review produced similar results (De Palma et al., 1996; Roseveare et al., 1998; Eickhoff et al., 2005). Furthermore, the perforation rates and early mortality rates were lower in those patients receiving SEMS. Rigid plastic stents are no longer used in oesophageal cancer.

Although the procedure-related complication rates are lower with SEMS, these devices are still subject to late complications including stent migration and stent occlusion due to food bolus or tumour overgrowth. One study has suggested that such late complications are more common with SEMS compared to rigid plastic stents (Kozarek et al., 1996). In a retrospective study of SEMS for malignant dysphagia, repeat endoscopy to address complications was needed in 46 of 97 patients, and in 10 of these a further stent had to be inserted (Ross et al., 2007). Acid reflux frequently occurs when stents are placed across, and thus hold open, the gastro-oesophageal junction. Patients with stents traversing the gastrooesophageal junction should experience fewer reflux symptoms if they take acid suppressive drugs to decrease gastric acid production, prokinetic drugs to hasten stomach emptying, avoid eating within 2-3 hours of bed-time, and elevate the head of the bed. Despite these measures patients can still experience significant reflux symptoms and consequently stents with inherent anti-reflux mechanisms have been developed e.g. the Oesophageal Z stent with Dua anti-reflux valve ${ }^{\circledR}$, (Cook Medical, Bloomington, USA), and the FerX-ELLA Esophageal Stent - Boubella ${ }^{\circledR}$, (ELLA-CS, Hradec-Kralove, Czech Republic).

\subsection{Types of expandable oesophageal stents used for oesophageal cancer}

The majority of commercially available oesophageal SEMS are made of nitinol or stainless steel. Covered stents are less prone to tumour ingrowth, but more prone to migration. Consequently partially covered stents have been developed. These have a central covered portion which is placed across the oesophageal tumour with the two ends left uncovered to allow embedding and anchoring into the adjacent tissue. Patients with partially covered stents have less tumour ingrowth and fewer interventions for recurrent dysphagia than patients with 
bare metal stents (Vakil et al; 2001; Saranovic et al., 2005). Studies comparing different commercially available covered stents have shown all the studied stents to have similar efficacy and complication rates (May et al., 1996; Sabharawal et al., 2003; Siersema et al., 2001).

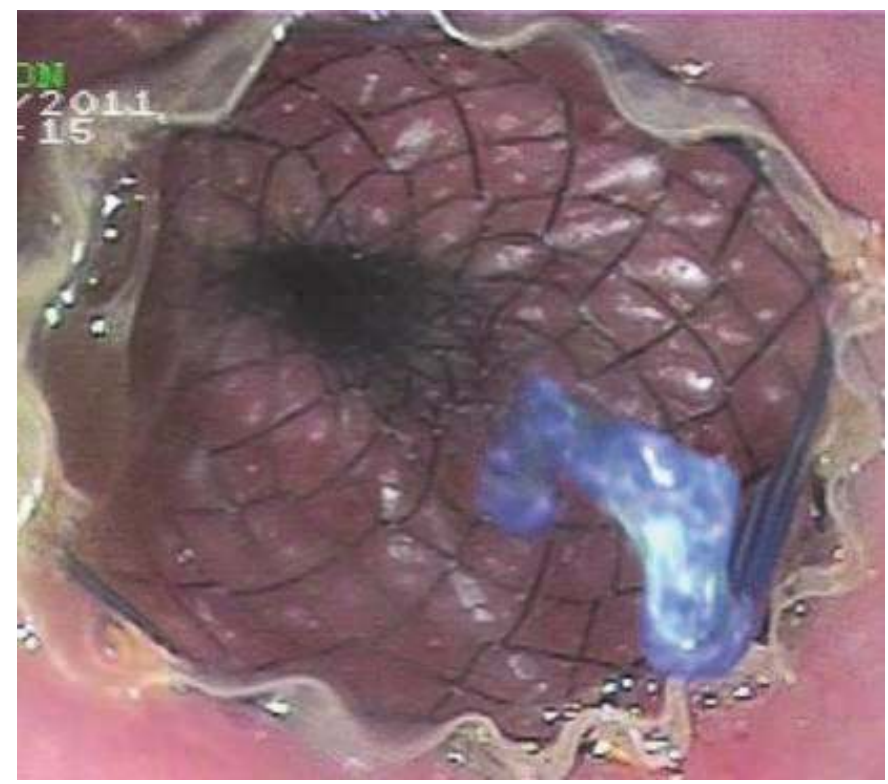

Fig. 5. Endoscopic view immediately after deployment of a SEMS for oesophageal cancer

In addition to SEMS, an self-expanding plastic stent made of polyester and covered with silicone (Polyflex ${ }^{\circledR}$, Boston Scientific, Natick, MA, USA) has become available. Randomised controlled studies have shown that it can be successfully placed in the majority of cases and produces similar improvements in dysphagia when compared to SEMS (Conio et al., 2007; Verschuur et al., 2008). However, self-expanding plastic stents are associated with more complications, in particular stent migration (Conio et al., 2007), and for this reason are not routinely used for the treatment of malignant oesophageal obstruction.

\subsection{Effect of oesophageal stenting on symptom palliation and quality of life}

SEMS improve swallowing in malignant dysphagia. When formally studied, SEMS have consistently been shown to improve dysphagia scores (Knyrim et al., 1993). Oesophageal SEMS enable patients to ingest semi-solids but rarely improve dysphagia to the point of taking a completely normal diet. Patients with SEMS run the risk of causing food bolus obstruction if they attempt to take an unrestricted diet. Roast meats and crusty bread are particular culprits in blocking stents. In addition to the symptomatic improvement some studies have documented a benefit in the overall quality of life (Diamantis et al., 2011). Karnofsky scores were shown to significantly improve from a median of 40 before SEMS insertion to a median of 65 after SEMS insertion (Knyrim et al., 1993). Other advantages of SEMS include nutritional benefits, with patients receiving SEMS enjoying food more and maintaining their weight longer compared to patient receiving rigid plastic stents (Roseveare et al., 1998). 


\subsection{Comparison of stenting with other palliative treatments in malignant dysphagia}

Alternative treatments for malignant dysphagia include endoscopic laser and brachytherapy. A multi-centre randomised trial found that SEMS improved dysphagia quicker than single dose brachytherapy, but brachytherapy was associated with better long term improvements in dysphagia, fewer complications and better quality of life scores (Homs et al., 2004). A Belgian centre retrospectively compared 125 patients with malignant dysphagia treated with endoscopic laser, rigid plastic stents and SEMS. Dysphagia improved significantly in all 3 groups but the rate of complications was significantly higher in both stent groups, compared to endoscopic laser (Gevers et al., 1998). In a prospective comparison, SEMS insertion was as safe and effective as laser combined with radiotherapy for inoperable oesophageal cancer (Königsrainer et al., 2000). SEMS insertion seems to be the preferred option for treating malignant dysphagia, since SEMS are widely available, relatively easy to place endoscopically or under fluoroscopic guidance, and provide rapid symptom relief. Brachytherapy, although efficacious remains a treatment that is not widely available.

\subsection{Stents for benign oesophageal peptic strictures}

Benign oesophageal strictures are most commonly caused by chronic reflux of gastric acid into the distal oesophagus. Such benign peptic strictures can lead to significant dysphagia. They are normally readily treated by endoscopic dilatation and acid suppression therapy. Rarely, the stricture repeatedly recurs within a few weeks. In these patients alternative treatments to repeated dilatation and acid suppressants may be needed. Although surgery is the mainstay of treatment in these refractory cases, oesophageal stenting should be considered in those less suitable for surgery. The ideal oesophageal stent for use in benign disease should, as with malignant disease, be easy to place, use a small calibre delivery mechanism and have a low rate of migration. However it should also be easy to retrieve, easy to reposition, and have low rates of insertion and removal related complications (Sharma \& Kozarek, 2010).

Data on the use of SEMS in benign oesophageal strictures come from case reports and case series. These reports show that SEMS are associated with high rates of complications. The most commonly reported are stent migration occurring in $12.5-31 \%$, new stricture formation in $20-100 \%$ and fistula formation in 6-33\% of patients (Sandha \& Marcon, 1999; Fiorini et al., 2000; Ackroyd et al., 2001; Wadhwa et al., 2003). Stent migration is more likely to occur with covered stents while uncovered stents or partially covered stents become embedded in the tissue making their removal difficult and traumatic. These complications rates are generally felt to be too high to justify in the treatment of benign disease. Therefore SEMS are best avoided in benign oesophageal strictures (Sharma \& Kozarek, 2010).

In distinction to metal stents, expandable plastic stents such as the removable Polyflex@ stent have been increasingly studied in benign oesophageal strictures that do not respond to conventional treatments. A recent meta-analysis of fully covered self-expanding metal and plastic stents has shown that the improvement in dysphagia was significantly better in patients receiving a Polyflex ${ }^{\circledR}$ stent $(55.3 \%)$ compared to those receiving a nitinol stent (21.8\%) (Thomas et al., 2011).

A more exciting prospect in the treatment of benign oesophageal conditions has been the recent development of biodegradable stents. Such stents are designed to stay in place for a few weeks before disintegrating. This avoids the need for further procedures to remove the stent. Some small series have now reported on their efficacy in benign strictures (Saito et al., 2007; Repici et al., 2010). 


\subsection{Stents for malignant tracheo-oesophageal fistulas}

Malignant tracheo-oesophageal fistulas may arise from infiltration of oesophageal cancers into the respiratory tract, or cancers of the trachea and bronchi infiltrating into the oesophagus. These life-threatening connections between the digestive tract and the airways are usually difficult to treat and are associated with poor prognosis. Patients receiving best supportive treatment survive a median of 22 days (Burt et al., 1991).There are no randomised controlled data on the use of SEMS in these patients. However, several case series have demonstrated that covered SEMS can lead to fistula occlusion in $70-100 \%$ of patients (May \& Ell, 1998). A retrospective study has shown covered SEMS to be more successful at fistula occlusion compared to rigid plastic stents, $92 \%$ vs. $77 \%$ (Low \& Kozarek, 1998). Furthermore, successful occlusion of the fistula was associated with improved 30 day survival, $90 \%$ vs. $25 \%$ (Dumonceau et al., 1999) and overall survival, 15.1 vs. 6.2 weeks (Shin et al., 2004).

\subsection{Stents for oesophageal perforations and leaks}

Spontaneous and iatrogenic perforations of the oesophagus also carry a very high mortality and morbidity. Early diagnosis and prompt treatment are essential to achieve a good outcome.

Spontaneous oesophageal perforation as a result of vomiting (Boerhaave's syndrome) is a surgical emergency, requiring surgical intervention within hours of the perforation. Rarely, patients present late and there have been a handful of reports of oesophageal SEMS being used in the treatment of spontaneous oesophageal perforations if the patient has presented late (Eubanks et al., 1999; Chung et al., 2001).

Iatrogenic perforations of the oesophagus are more common than spontaneous perforations. They usually occur at endoscopy, most frequently when malignant stricture dilatation is undertaken. The diagnosis of perforation is usually obvious and rapid. Although iatrogenic oesophageal perforation is life-threatening, contamination of the mediastinum and pleural space with stomach contents is less problematic compared to spontaneous perforation, since the patient is fasted. Small case series have shown that insertion of a covered SEMS, together with thoracostomy tube drainage of the pleural space and antibiotic administration is a successful strategy in sealing off iatrogenic perforations (Siersema et al., 2003). Prompt stent insertion (average delay 45 minutes) after iatrogenic oesophageal perforation leads to minimal morbidity compared to delayed treatment, and produces results similar to surgical treatment (Fischer et al., 2006). It has to be emphasised that the clinical state of patients may individualise therapy for oesophageal perforations; although most centres consider surgery as first-line therapy (Keeling et al., 2010; Kiernan et al., 2010), endoscopic stenting is an option in many patients (Johnsson et al., 2005; van Heel et al., 2010).

\subsection{Oesophageal stenting for anastomotic leaks}

Post-operative anastomotic leaks are another area where oesophageal stents are increasingly used. Case series of anastomotic leaks following upper gastrointestinal surgery have demonstrated high success and low complications rates, with patients returning to eating 2 days after stent insertion.

\subsection{Stenting for bleeding oesophageal varices}

Oesophageal stents have recently been used to arrest bleeding from oesophageal varices in patients with portal hypertension. Bleeding from oesophageal varices has a high mortality, 
especially in patients with advanced liver disease. Bleeding is usually controlled by endoscopic band ligation of the varices, and vasopressor medication to decrease portal pressure. If these measures fail, the bleeding can be controlled with the insertion of a Sengstaken-Blakemore tube which tamponades the varices. Balloon tamponade is a temporary measure often used as a bridge to treatment with a transjugular intrahepatic portosystemic stent shunt (TIPSS).

A covered self-expanding oesophageal stent (SX-Ella Stent Danis®,ELLA-CS, Hradec-Kralove, Czech Republic) has recently been developed as another treatment option in variceal bleeding. It is an alternative to balloon tamponade in patients who are not suitable for TIPSS or in whom Sengstaken-Blakemore tube insertion is not possible, has failed or is complicated by oesophageal perforation. The SX-Ella Stent Danis ${ }^{\circledR}$ delivery mechanism is inserted over a guidewire that has been endoscopically placed in the stomach. The endoscope is then withdrawn and the delivery mechanism advanced through the oesophagus into the stomach. A balloon located at the stent's distal end is then inflated, and the whole mechanism is withdrawn until the balloon reaches the cardia and resistance is felt. The stent, now positioned in the distal oesophagus can be deployed, followed by balloon deflation and removal of the delivery mechanism. The stent can also be placed without prior endoscopy in emergency situations. Once deployed, the tamponading stent permits ongoing oral nutrition, unlike balloon tamponade. Case series show that such stents are efficacious in bleeding oesophageal varices. They can be successfully placed in the majority of patients and are removed within 14 days of insertion. The only complication that has been reported is of oesophageal ulceration (Hubmann et al., 2006; Zehetner et al., 2008; Wright et al., 2010).

\section{Gastroduodenal stents}

Recurrent and distressing vomiting due to gastric outlet obstruction occurs in some patients with pancreatic cancer, distal gastric cancer, duodenal cancer and some metastatic cancers. Most of these patients have advanced and inoperable disease, and only a few months of life remaining. Until recently the only treatment to prevent relentless vomiting and allow oral nutrition was the fashioning of a surgical gastroenterostomy to bypass the antro-pyloroduodenal region. Even though such surgery can now often be done laparoscopically, complications are not uncommon in such patients who are often malnourished and frequently have comorbidities. The development of gastroduodenal stent insertion offers a noninvasive means of palliating vomiting without surgery (Martin \& Laasch, 2004; Lowe et al., 2007; Kim et al., 2007).

Gastroduodenal stents are of the SEMS variety and are positioned under direct endoscopic vision, and with fluoroscopic guidance. Before stent placement is attempted, a period of gastric drainage using a wide-bore nasogastric tube is recommended. Drainage of gastric contents will improve endoscopic views and reduce the risk of vomiting and aspiration during the procedure. At endoscopy, the stricture's proximal anatomy is assessed but usually the endoscope's diameter is too large to allow safe negotiation through the stricture. The stricture can be outlined by fluoroscopy after the injection of a contrast agent. A guidewire is then passed down the operating channel of a therapeutic endoscope and advanced through the stricture. The stent assembly is then passed over the wire and positioned so that its ends overlap the ends of the stricture. Once fluoroscopy confirms a satisfactory position, the SEMS is deployed. An alternative method of gastroduodenal stent insertion involves a radiologist placing the stent via the oral route using fluoroscopy alone. 
Once a gastroduodenal stent has been sited, patients can resume oral intake without vomiting. Patients should be advised to chew all foods well, and initially a soft diet is recommended. Patients who remain on a semi-solid diet are less likely to experience food impaction in their stent, but many patients are able to tolerate all food consistencies. Following gastroduodenal stent insertion, potential early complications include bleeding and perforation. Late complications include distal stent migration, and stent obstruction by tumour ingrowth, reactive tissue hyperplasia, tumor overgrowth, and food impaction.

\subsection{Endoscopic stenting $v$. gastrojejunostomy in malignant gastric outlet obstruction}

Most comparisons of gastroduodenal stent insertion with surgical gastrojejunostomy in malignant outlet obstruction have been retrospective. There is little in the way of large randomised trial data prospectively comparing these two palliative procedures. Despite the limitations of studies to date, some conclusions can be drawn (Gaidos \& Draganov, 2009; Ly et al., 2010). Compared to surgical gastrojejunostomy, gastroduodenal stent insertion is associated with a shorter hospital stay, fewer costs (Johnsson et al., 2004) and fewer complications at the time of intervention. Stent insertion also leads to faster resumption of oral food intake than surgical gastrojejunostomy (Maettani et al., 2004; Ly et al., 2010). However, in the longer term there may be stent migration or obstruction, and long term results are better with surgery (Jeurnink et al., 2010).

\subsection{Combined biliary and gastric outlet obstruction}

By the time an inoperable pancreatic cancer causes gastric outlet obstruction, there has often already been biliary obstruction. Endoscopic access to the duodenal papilla is important for biliary stenting and jaundice relief (see below). A gastroduodenal stent will cover the duodenal papilla, but with an uncovered stent some endoscopic access to the papilla can be achieved through the holes in the metal mesh. However it is technically very difficult to perform biliary stenting though the mesh of an uncovered metal duodenal stent, and biliary stent insertion or exchange is more readily achieved percutaneously via the transhepatic cholangiographic route once a gastroduodenal stent is present. Covered gastroduodenal stents will further confound endoscopic access to the duodenal papilla and impede percutaneous biliary stent placement, as well as being more likely to migrate. Consequently uncovered gastroduodenal stents are most frequently used in gastric outlet obstruction due to pancreatic head cancers.

Simultaneous biliary and gastroduodenal metal stenting can be done in patients with inoperable pancreatic cancers causing obstructive jaundice and gastric outlet obstructive symptoms (Kaw et al., 2003; Mutignani et al., 2007). Whenever a gastroduodenal stent is to be inserted in a pancreatic cancer patient, consideration should be given to initially stenting the bile duct. A pre-existing plastic biliary stent can be changed for a wider biliary SEMS before the gastroduodenal stent is placed. If the duodenal obstruction does not allow passage of the duodenoscope to reach the ampullary region, then transhepatic insertion of a biliary SEMS should be considered prior to placing the gastroduodenal stent.

\section{Biliary stents}

\subsection{Biliary strictures}

Biliary stents are inserted at Endoscopic Retrograde Cholangio-Pancreatography (ERCP) in the setting of malignant bile duct strictures (pancreatic head cancers and 
cholangiocarcinomas). At ERCP, biliary stents are positioned through a side-viewing duodenoscope under direct endoscopic vision, and with fluoroscopic guidance. Despite advances in healthcare, most patients with malignant biliary strictures are not surgically curable. The obstructive jaundice and pruritus arising from blockage to the flow of bile into the duodenum can be very distressing. Endoscopic biliary stenting at ERCP provides relief from obstructive jaundice and pruritus, with associated improvement in quality of life (Ballinger et al., 1994). Stents used can be plastic or SEMS. Prior to the development of endoscopic stenting, relief of obstructive jaundice in unresectable malignant disease required a surgical biliary bypass operation. The first endoscopic transpapillary biliary stent insertion was performed in 1979 (Soehendra et al., 1980).

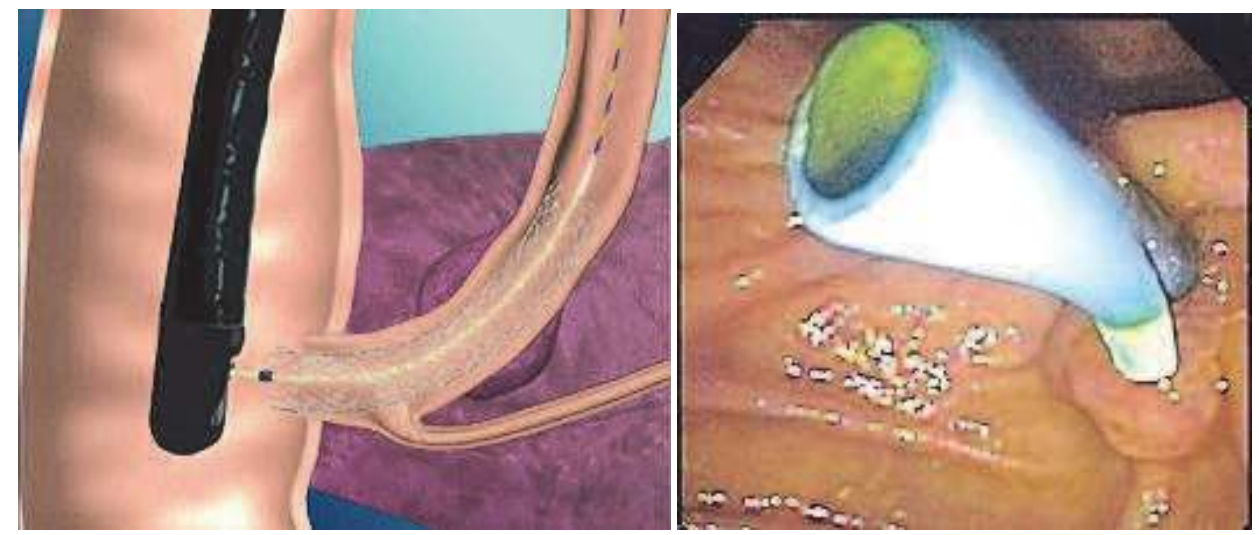

Fig. 6. Diagram of a SEMS deployed in distal bile duct at ERCP (left panel), and endoscopic view of a plastic biliary stent protruding from the duodenal ampulla in a patient with pancreatic cancer (right panel)

\subsubsection{Role of stenting in obstructive jaundice due to operable pancreatic head carcinoma}

Approximately $20 \%$ of patients with pancreatic cancer have localised disease making a surgical resection technically possible. Surgical candidates for the required pancreaticoduodenectomy (Whipple's procedure) may require preoperative biliary stenting to improve symptoms of obstructive jaundice while awaiting surgery. Furthermore, traditional surgical teaching has stated that operating in the presence of obstructive jaundice is linked to increased postoperative complications, and that the biochemical correction of jaundice preoperatively is linked to fewer surgical complications. However there are now increasing data indicating that preoperative biliary drainage using plastic stents may not actually be beneficial but may even be associated with more complications, particularly from cholangitis (van der Gaag et al., 2010). Therefore, if there is no time delay to surgical resection, preoperative biliary drainage using endoscopic stenting is best avoided.

\subsubsection{Biliary stenting v. surgery for jaundice in unresectable pancreatic head carcinoma}

Most $(80 \%)$ patients with pancreatic head cancers and consequent biliary tract obstruction are not candidates for surgical resection. This is because of locally advanced disease (particularly infiltration of the major mesenteric vessels) or distant metastases, or patient 
frailty/comorbidities. Until the advent of biliary stenting, obstructive jaundice and pruritus could only be relieved by a palliative surgical biliary bypass procedure (cholecystojejunostomy or choledochojejunostomy). The introduction of plastic biliary stent placement at ERCP has allowed a non-invasive means of palliating jaundice and pruritus. Comparative trials of plastic stent placement with biliary bypass operations have shown similar survival outcomes, but stenting is associated with fewer complications, less use of resources and a shorter period of hospitalisation (Shepherd et al., 1988; Andersen et al., 1989; Smith et al., 1994; Moss et al., 2007). However plastic biliary stenting is associated with a higher risk of recurrent biliary obstruction than surgery. There have been no direct prospective trials comparing SEMS with biliary bypass surgery.

\subsubsection{Plastic stents v. SEMS in unresectable pancreatic head carcinoma}

Plastic stents tend to become blocked with biliary sludge and bacterial biofilm formation. A standard plastic 10 Fr stent may only last 3-5 months. A blocked stent will lead to a recurrence of jaundice and frequently cholangitis too. In the setting of inoperable pancreatic head cancer, the short life-span of the plastic stent is often greater than the life expectancy of the patient. Therefore although there is no doubt that modern biliary SEMS are less likely to become blocked (Davids et al., 1992; Moss et al., 2007; Weber et al., 2009), their superior patency over plastic stents will not become manifest in pancreatic head cancer patients with short life expectancy (Moss et al., 2006; Gronroos et al., 2010).
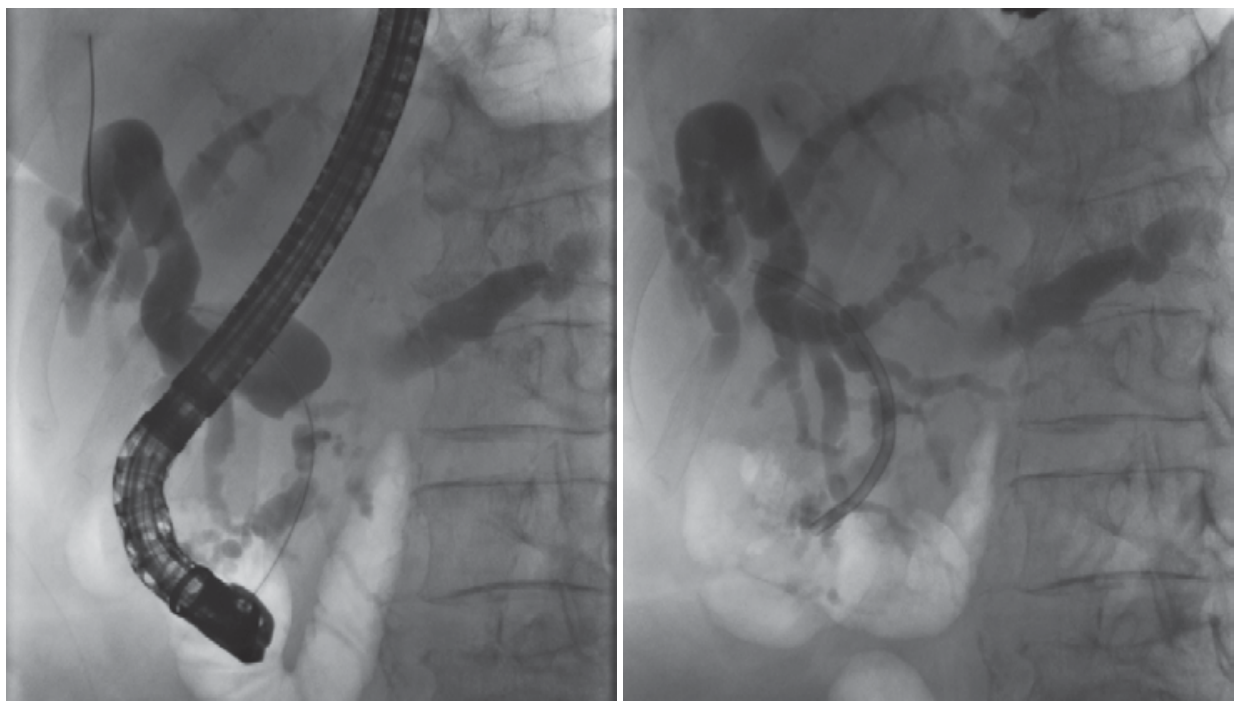

Fig. 7. ERCP images in a patient with carcinoma of head of pancreas. A wire has been placed across a stricture of the distal common bile duct into the dilated obstructed biliary system above (left hand image). Following insertion of a plastic stent (right hand image).

Wider plastic stents will remain patent for longer, but 12 Fr currently represents the maximum diameter of a plastic biliary stent since it is limited by the diameter of the duodenoscope's operating channel. Biliary stents, whether plastic or metal, traverse the Sphincter of Oddi which is the physiological barrier preventing bacteria from the duodenum refluxing into the 
biliary system. Since occlusion of biliary stents is in part due to bacterial biofilm formation, consideration has been given to prolonging stent patency by impregnating stents with antimicrobial agents or coating them with silver or hydrophilic polymer which reduce bacterial adhesion. However these approaches are based on in vitro observations and have not been translated into clinical advantage (Schilling et al., 2003; Donelli et al., 2007). Similarly administering oral antibiotics or using the choleretic agent ursodeoxycholic acid does not reliably lead to prolongation of plastic stent patency (Galandi et al., 2002).

For patients with inoperable pancreatic head cancer whose survival is predicted to be several months or longer, and for patients who cannot undergo resective surgery for distal common bile duct cholangiocarcinomas or ampullary tumours (both slower growing than pancreatic cancers), SEMS placement is superior to plastic stent placement. Biliary SEMS remain patent for longer periods than plastic stents (Moss et al., 2006). At least in part this is due to the fact that the diameter of a biliary SEMS is three times that of plastic stent. Biliary SEMS are far more costly than plastic stents, but their use is justified in patients whose survival is predicted to be more than 6 months since a repeat endoscopic procedure to replace an occluded plastic stent is likely to be needed by then. Although SEMS undoubtedly have greater patency, tumour tissue may grow through the gaps in the metal mesh leading to subsequent occlusion. The stent can be unblocked by trawling a balloon through its lumen, by using diathermy devices or by placing another (metal or plastic) stent within it. Tumour ingrowth can be offset by using silicone-covered biliary stents, but as with all covered stents these are more likely to migrate, compared to uncovered bare metal stents. In the constant quest to improve stent design, a biliary SEMS incorporating a novel antireflux device has been developed with the hope that preventing reflux of duodenal contents into the biliary tract will aid stent patency (Hu et al., 2011).

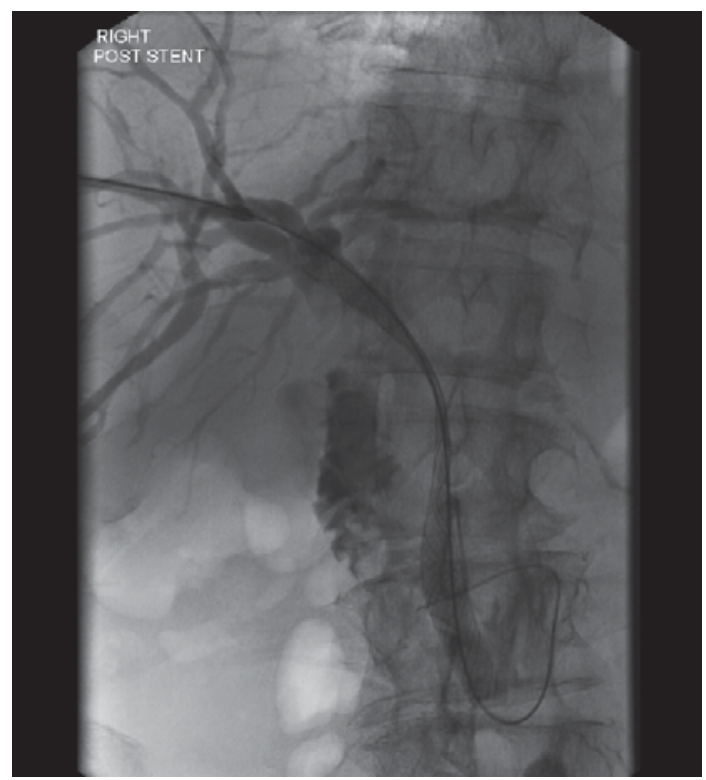

Fig. 8. SEMS being deployed across a malignant stricture of the common bile duct at transhepatic cholangiography 


\subsubsection{Biliary stenting in obstructive jaundice due to unresectable hilar malignancies}

Malignant biliary obstruction at the liver hilum is usually due to cholangiocarcinoma, a primary cancer originating from the biliary ductal system (Aljiffry et al., 2009). Metastatic cancer infiltrating lymph nodes at the liver hilum can also cause stricturing at this site. While the most proximal cholangiocarcinomas originate from either the right or the left intrahepatic ductal system, cholangiocarcinomas more commonly involve the confluence of the two ductal systems where they join to form the common hepatic duct and are then known as hilar tumours. These intrahepatic and hilar chlangiocarcinomas often cause obstructive jaundice and pruritus. The only chance of a cure is a hepatic resection, but for many patients this is not an option due to advanced disease or due to frailty/comorbidities. In unresectable disease, palliation of jaundice and pruritus may be achieved by biliary stenting.

Stenting across malignant hilar strictures can be technically challenging at ERCP. Prior imaging of the biliary ductal system using Magnetic Resonance Cholangio-Pancreatography (MRCP) provides invaluable information before stenting is attempted. Strictures at the liver hilum may be complex and it may not be possible to drain obstructed liver segments at ERCP. There is a significant risk of causing cholangitis by injecting contrast medium into undrained ductal segments, therefore drainage of contrast-filled obstructed biliary branches is crucial. There has been much debate about the importance of establishing drainage of both liver lobes in malignant hilar obstruction. Although the right hepatic duct drains a greater volume of liver than the left hepatic duct, successful stenting of either side achieves a similar symptomatic and biochemical improvement (Polydoru et al., 1989). A randomised trial comparing the insertion of a single plastic stent to drain one side of the liver with placing two plastic stents to drain both sides, found that there was no advantage in placing two stents. Attempts to place two stents were associated with more complications, particularly cholangitis (de Palma et al., 2001). Extrapolating from this, it would seem that that if endoscopic stenting is to be performed for malignant hilar strictures, then a single SEMS is the best strategy. As with distal biliary strictures SEMS are less likely than plastic stents to occlude (Perdue at al., 2008).

Satisfactory biliary drainage of hilar strictures may not be possible at ERCP. Percutaneous hepatic drainage and stenting can be performed by an interventional radiologist if initial ERCP is unsuccessful, or if following endoscopic stenting there are undrained hepatic segments requiring treatment. Percutaneous stenting is performed using local anaesthetic and with intravenous sedation. Initial percutaneous transhepatic cholangiography will delineate the strictured area at the hilum and, usually after a period of external biliary drainage, a stent can be positioned at a second percutaneous transhepatic biliary procedure. ERCP and percutaneous transhepatic biliary radiology are thus complimentary interventions in the approach to proximal obstructive biliary strictures. There are few data comparing endoscopic and percutaneous stenting for hilar strictures. One retrospective study concluded that biliary decompression using SEMS was more likely to be successful if the SEMS was inserted via the percutaneous transhepatic route than if inserted via the endoscopic route (Paik et al., 2009).

\subsection{Biliary stenting for common bile duct stones (choledocholithiasis)}

Choledocholithiasis can lead to pain, obstructive jaundice, acute pancreatitis and cholangitis. Endoscopic removal of stones at ERCP is safer than open surgical exploration of the common bile duct. Common bile duct stone extraction at ERCP is usually successful using balloon 
catheters, baskets or lithotripsy after performing endoscopic sphincterotomy or sphincteroplasty (Williams et al., 2008). However it is not always possible to clear the common bile duct of stones, particularly large stones. The insertion of a stent to splint residual stone(s) is a reasonable temporary strategy, although it is preferable to clear the duct completely at a later procedure. Biliary stents used to splint common bile duct stone(s) are typically of the plastic pigtail variety. They are usually of smaller calibre, typically $7 \mathrm{Fr}$ and inserted over a guidewire. The pigtail stent splints the stone within the bile duct, allowing bile to drain around it, and does not rely solely on the stent remaining patent. Stent placement for choledocholithiasis is a good temporising intervention in the setting of common bile duct stone(s) causing jaundice and/or cholangitis (Cairns et al., 1989; Maxton et al., 1995). Previously nasobiliary drainage was used as an emergency intervention in patients with lifethreatening supporative cholangitis but the placement of a plastic stent provides as effective biliary drainage in this acute emergency (Sharma et al., 2005; Park et al., 2008).

If intervention at the index ERCP does not clear common bile duct stones and a stent is left in situ to provide drainage, then a follow up ERCP or surgical exploration of the common bile duct will be necessary (Williams et al., 2008). A second therapeutic ERCP after an interval is often successful at clearing the common bile duct (Maxton et al., 1995; Horiuchi et al., 2010). Clearing the bile duct is the preferred management course since the retention of common bile duct stones and ongoing presence of a plastic splinting stent makes a bout of future cholangitis more likely (Bergman et al., 1995; Chopra et al., 1996). Only patients who have limited life expectancy, or who have significant comorbidity should have plastic biliary stents left as sole therapy for their retained common bile duct stones (van Steenbergen et al., 1992; Williams et al., 2008).

\subsection{Stenting for biliary leaks following cholecystectomy}

Biliary leaks are not uncommon after cholecystectomy (Lau et al., 2010), and the advent of the laparoscopic approach to cholecystectomy has, if anything, made this surgical complication more common. Biliary leaks usually become evident in the early post-operative period, and may arise from an inadvertent intraoperative bile duct injury, or from the clips on the transected cystic duct becoming displaced. Once it is evident that a biliary leak with consequent biliary peritonitis is occurring, endoscopic treatment at ERCP is the preferred intervention (Tzovaras et al., 2001; Sandha et al., 2004; Agarwal et al., 2006). Endoscopic sphincterotomy alone will reduce pressure in the biliary system by equating it with intraduodenal pressure. The elimination or reduction in pressure gradient promotes preferential flow of bile from the common bile duct into the duodenum instead of extravasation via the leak. This allows a more proximal bile duct leak or cystic duct stump leak to heal spontaneously. However many endoscopists prefer to insert a temporary plastic stent. This can be a short stent across the Sphincter of Oddi, again effectively reducing pressure in the biliary system, so that the defect can heal spontaneously (Bjorkman et al., 1995). Alternatively a longer stent can be placed to cover the leak. For example in the case of a leaking cystic duct stump, a long straight plastic stent might be positioned with the proximal end above the junction of the cystic duct and bile duct. Endoscopically-placed plastic stents can be removed after approximately 6 weeks, by which time the biliary leak will have healed.

\subsection{Stenting of biliary strictures caused by cholecystectomy or liver transplant}

Bile duct stricturing may complicate bile duct injury at cholecystectomy. Traditionally a hepaticojejunostomy has been the definitive treatment for such stricturing after 
cholecystectomy. However endoscopic access to the common bile duct at ERCP allows balloon dilatation and the insertion of a plastic biliary stent across the stricture. If plastic stents are routinely changed (to avoid clogging) every 3 months, then after approximately one year, stents can then be removed and in most cases the stricturing will not recur (de Palma et al., 2003; Vitale et al., 2008).

Biliary stricturing remains a common problem after orthotopic liver transplantation (Ayoub et al., 2010). The two usual types of bile duct reconstruction performed at the time of transplantation are duct-to-duct (choledocho-choledochostomy) and hepatico-jejunostomy. Duct-to-duct biliary reconstructions allow endoscopic access to the reconstructed bile duct. Strictures of the biliary anastomosis are characteristically localised and short. They respond well to endoscopic treatment with balloon dilatation and plastic biliary stenting (Seo et al., 2009). However transplant recipients may also experience non-anastomotic strictures which are a consequence of ischaemia or immunological reaction. These non-anastomotic strictures may be more diffuse and longer. They respond less well to endoscopic therapy with repeated dilatations and stenting (Williams \& Draganov, 2009).

\section{Pancreatic stents}

Stenting of the pancreatic duct at ERCP is used in chronic pancreatitis, pancreatic duct leaks and the prevention of ERCP-induced pancreatitis. Invariably plastic stents are used in these settings. The pancreatic duct is much narrower than the biliary ductal system, and stents in the pancreatic duct can induce fibrosis and stricturing.

\subsection{Chronic pancreatitis}

Refractory pain in chronic pancreatitis may be associated with an obstructed pancreatic duct. In patients suffering ongoing pain due to chronic pancreatitis, pancreatic stenting helps relieve pressure in a pancreatic duct obstructed by an inflammatory stricture or stone, often with subsequent pain relief (Wilcox \& Varadarajulu, 2006, Weber et al., 2007, NguyenTang \& Dumonceau, 2010). Patients with a dominant pancreatic duct stricture in the pancreatic head seem to derive most benefit from such transpapillary stent placement. However well-performed prospective controlled studies of pancreatic endoscopic therapy for chronic pancreatitis are lacking. Furthermore, pancreatic duct stenting is inferior to surgical drainage in relieving pain associated with an obstructed pancreatic duct (Cahen et $\mathrm{al}$, 2007). When pancreatic stents are used in chronic pancreatitis, endoscopists typically use stent calibres ranging from $7 \mathrm{Fr}$ to $11.5 \mathrm{Fr}$, and elective stent changes are needed every 2-3 months. Smaller calibre stents will occlude more easily and need more frequent changing.

\subsection{Pancreatic duct fistulae}

The pancreatic duct can be disrupted by an attack of acute pancreatitis or following surgery. Subsequent pancreatic duct leaks with/without pseudocyst formation can be treated by the insertion of a transpapillary pancreatic duct stent (Cicek et al,, 2006). Any discrete connection between the pancreatic duct and a pancreatic pseudocyst can be sealed off by the insertion of a pancreatic stent.

\subsection{Preventing ERCP-induced pancreatitis}

Acute pancreatitis is a recognised complication of ERCP, occurring in up to approximately $5 \%$ of therapeutic ERCPs (Freeman et al., 1996; Arata et al., 2010). The risk of pancreatitis is 
greater in some patient categories (Cheng et al., 2006), and may be as great as $20-30 \%$ in women with Sphincter of Oddi dysfunction. Pancreatic stent placement decreases the risk of post-ERCP pancreatitis in high-risk patients (Arata et al., 2010; Choudhary et al., 2011). Typically 5 Fr or 3 Fr gauge straight stents are used. Unflanged stents are advantageous in this setting since they are more likely to spontaneously dislodge, and a second endoscopic procedure to remove the stent is avoided.

\section{Colorectal stents}

Colorectal cancer is usually treated by planned surgery, but many patients present as an emergency with acute colonic obstruction. Colorectal SEMS can be used in the treatment of acute malignant colonic obstruction as a bridge to definitive surgery. Secondly, some patients with colonic cancers which are starting to produce obstructive symptoms may not be surgical candidates due to metastatic disease or frailty/comorbidities. These patients can be electively palliated using SEMS.

Colonic SEMSs are usually uncovered and can be inserted with a combination of endoscopy and fluoroscopic guidance. Typically an endoscope is used to identify the obstructing cancer, and a wire is passed through the stricture and into the proximal bowel. The endoscope is then withdrawn and the stent delivery mechanism is fed over the wire. The endoscope can be reinserted alongside the stent delivery mechanism and together with fluoroscopy can be used to guide the deployment of the stent across the obstructing lesion. For obstructing cancers in the proximal colon, stent placement is best achieved using a "through the scope" delivery mechanism. The stent delivery mechanism is delivered over a guidewire through the working channel of a colonoscope and deployed without removing the colonoscope.

\subsection{Colorectal SEMS for acute colonic obstruction}

Up to $20 \%$ of patients with colon cancer initially present with symptoms of acute colonic obstruction. Obstruction is more common in the distal colon, which has a smaller calibre than the proximal colon. Emergency surgery plays a major role in the management of these patients. However, emergency decompressive surgery on the unprepared and obstructed bowel, in patients who are often very sick, carries a significant risk of morbidity (32\%-64\%) and mortality (15\%-34\%) (McLoughlin \& Byrne, 2008).

Emergency surgical decompression invariably involves colostomy formation, since primary anastomosis in the setting of an unprepared and obstructed bowel is likely to break down. Operations range from a loop colostomy, a Hartmann's procedure or sometimes a subtotal colectomy. Following such emergency surgery, a patient with a potentially resectable cancer will then require a planned second operation at a later stage. However, in up to $40 \%$ patients the colostomy becomes permanent and will not be closed because of metastatic disease or frailty.

Placement of a colonic SEMS to relieve the malignant obstruction in the emergency setting will spare the patient emergency surgery and colostomy formation. Stenting allows time for the patient to recover from acute symptoms, and undergo appropriate cancer staging investigations. In patients whose staging investigations confirm operable cancer, stenting as a bridge to a definitive resection allows better preparation for the surgery which is less likely to then involve stoma formation. In these situations the stent is removed together with the resected tumour. In patients whose staging investigations reveal inoperable cancer, the stent provides palliation. 
Early studies showed that colorectal stents inserted under a combination of endoscopic and fluoroscopic (Baron et al., 1998) or fluoroscopic guidance alone (Mainar et al., 1996) are safe and effective in the treatment of acute malignant colonic obstruction. A randomised study of 48 patients with obstructing left distal colonic cancers compared SEMS placement followed by definitive laparoscopic-assisted colonic resection and conventional emergency open surgery. Patients in the SEMS / laparoscopic surgery group were more likely to have a successful single stage operation $(67 \%$ vs $38 \%)$, less likely to have a permanent stoma ( $0 \%$ vs $25 \%$ ), and less likely to have complications than the emergency surgery group (Cheung et al., 2009). In another prospective randomised study, obstructed patients who were stented prior to surgery were also more likely to have a primary anastomosis compared to those who had emergency surgery ( $85 \%$ vs $41 \%)$. They also had fewer complications, reinterventions and a reduced total hospital and ITU stay (Martinez-Santos et al., 2002). In a meta-analysis that included non randomised and somewhat heterogeneous studies comparing SEMS and open surgery for malignant large bowel obstruction, mortality was $5.7 \%$ in those undergoing SEMS compared to $12.1 \%$ in those having emergency surgery (Tilney et al., 2007).

\subsection{Colorectal SEMS for palliation of incurable colonic cancer}

SEMS are also used electively for palliation of symptoms in patients who are frail and not fit for surgery, or in cases of advanced cancer. Two small randomised controlled trials have compared SEMS to colostomy for the palliation of malignant obstruction (Fiori et al., 2004; Xinopoulos et al., 2004). They found that patients who were treated with SEMS spent less time in hospital and had a shorter time to oral intake and restoration of bowel function. A recent retrospective study from a single centre also showed a high technical and clinical success rate for SEMS insertion, with few complications up to 30 days after stent insertion. However complications (mainly stent re-obstruction and stent migration necessitating the placement of a second stent) after 30 days were higher in patients treated with SEMS than in those treated with surgery (Lee et al., 2011).

\subsection{Technical success and complications associated with colorectal SEMS}

Colonic stents have now been used in malignant colorectal obstruction for two decades. Two systematic reviews of non randomised studies (Khot et al., 2002; Sebastian et al., 2004) conclude that colonic stents can be successfully placed in the majority of cases $(92 \%$ and $94 \%$ ) with a good clinical result (88\% and 91\%). Complications in these reviews included perforation in about $4 \%$, stent migration in $10 \%$ and re-obstruction in $10 \%$ of patients. Stent related mortality is approximately $1 \%$. Based on the available data, the World Society of Emergency Surgery and the Peritoneum and Surgery Society advocate the use of colorectal stents in preference to colostomy in cases where palliation is needed, and endorse their use as a bridge to surgery in cases of acute malignant colonic obstruction (Ansaloni et al., 2010) SEMS insertion for benign diseases of the colon is somewhat controversial. The role for SEMS in treating benign colonic strictures has yet to be established.

\section{Summary}

Advances in endoscopy and in stent technology in the past 20 years have allowed noninvasive palliation of obstructive symptoms within the gastrointestinal tract using stents. In many clinical scenarios, stent placement has proved advantageous over surgery. 


\section{Acknowledgments}

Figures of in vitro stents are reproduced with permission from Cook Medical and Olympus.

\section{References}

Ackroyd, R., Watson, D. I., Devitt, P. G. \& Jamieson, G. G. (2001). Expandable metallic stents should not be used in the treatment of benign esophageal strictures. J Gastroenterol Hepatol, 16, 484-7.

Agarwal, N., Sharma, B. C., Garg, S., Kumar, R. \& Sarin, S. K. (2006). Endoscopic management of postoperative bile leaks. Hepatobiliary Pancreatic Dis Int, 5, 273-7.

Aljiffry, M., Walsh, M. J. \& Molinari, M. (2009). Advances in diagnosis, treatment and palliation of cholangiocarcinoma: 1990-2009. World J Gastroenterol, 15, 4240-62.

Andersen, J. R., Sørensen, S. M., Kruse, A., Rokkjaer, M. \& Matzen, P. (1989). Randomised trial of endoscopic endoprosthesis versus operative bypass in malignant obstructive jaundice. Gut, 30, 1132-5.

Ansaloni, L., Andersson, R. E., Bazzoli, F., Catena, F., Cennamo, V., Di Saverio, S., Fuccio, L., Jeekel, H., Leppäniemi, A., Moore, E., Pinna, A. D., Pisano, M., Repici, A., Sugarbaker, P. H. \& Tuech, J. J. (2010). Guidelines in the management of obstructing cancer of the left colon: consensus conference of the world society of emergency surgery (WSES) and peritoneum and surgery (PnS) society, World J Emerg Surg, 28, 29.

Arata, S., Takada, T., Hirata, K., Yoshida, M., Mayumi, T., Hirota, M., Yokoe, M., Hirota, M., Kiriyama, S., Sekimoto, M., Amano, H., Wada, K., Kimura, Y., Gabata, T., Takeda, K., Kataoka, K., Ito, T. \& Tanaka, M. (2010). Post-ERCP pancreatitis. J Hepatobiliary Pancreat Sci, 17, 70-8.

Ayoub, W. S., Esquivel, C. O. \& Martin, P. (2010). Biliary complications following liver transplantation. Dig Dis Sci, 55, 1540-6.

Ballinger, A. B., McHugh, M., Catnach, S. M., Alstead, E. M. \& Clark, M. L. (1994). Symptom relief and quality of life after stenting for malignant bile duct obstruction. Gut, 35, 467-70.

Baron, T. H., Dean, P. A., Yates 3rd, M. R., Canon, C. \& Koehler, R. E. (1998). Expandable metal stents for the treatment of colonic obstruction: techniques and outcomes, Gastrointest Endosc, 47, 277-86.

Bergman, J. J., Rauws, E. A., Tijssen, J. G., Tytgat, G. N. \& Huibregtse, K. (1995). Biliary endoprostheses in elderly patients with endoscopically irretrievable common bile duct stones: report on 117 patients. Gastrointest Endosc, 42, 195-201.

Bethge, N., Sommer, A., Gross, U., von Kleist, D. \& Vakil, N. (1996). Human tissue responses to metal stents implanted in vivo for the palliation of malignant stenoses. Gastrointest Endosc, 43, 596-602.

Bjorkman, D. J., Carr-Locke, D. L., Lichtenstein, D. R., Ferrari, A. P., Slivka, A., Van Dam, J. \& Brooks, D. C. (1995). Postsurgical bile leaks: endoscopic obliteration of the transpapillary pressure gradient is enough. Am J Gastroenterol, 90, 2128-33.

Burt, M., Diehl, W., Martini, N., Bains, M. S., Ginsberg, R. J., McCormack, P. M. \& Rusch, V. W. (1991). Malignant esophagorespiratory fistula: management options and survival. Ann Thorac Surg, 52, 1222-8.

Cahen, D. L., Gouma, D. J., Nio, Y., Rauws, E. A., Boermeester, M. A., Busch, O. R., Stoker, J., Laméris, J. S., Dijkgraaf, M. G., Huibregtse, K. \& Bruno, M. J. (2007). Endoscopic 
versus surgical drainage of the pancreatic duct in chronic pancreatitis. $N$ Engl J Med, 356, 676-84.

Cairns, S. R., Dias, L., Cotton, P. B., Salmon, P. R. \& Russell, R. C. (1989). Additional endoscopic procedures instead of urgent surgery for retained common bile duct stones. Gut, 30, 535-40.

Cheng, C. L., Sherman, S., Watkins, J. L., Barnett, J., Freeman, M., Geenen, J., Ryan, M., Parker, H., Frakes, J. T., Fogel, E. L., Silverman, W. B., Dua, K. S., Aliperti, G., Yakshe, P., Uzer, M., Jones, W., Goff, J., Lazzell-Pannell, L., Rashdan, A., Temkit, M. \& Lehman, G. A. (2006). Risk factors for post-ERCP pancreatitis: a prospective multicenter study. Am J Gastroenterol, 101, 139-47.

Cheung, H. Y., Chung, C. C., Tsang, W. W., Wong, J. C., Yau, K. K. \& Li, M. K. (2009). Endolaparoscopic approach vs conventional open surgery in the treatment of obstructing left-sided colon cancer: a randomized controlled trial. Arch Surg, 144, 1127-32.

Chopra, K. B., Peters, R. A., O'Toole, P. A., Williams, S. G., Gimson, A. E., Lombard, M. G. \& Westaby, D. (1996). Randomised study of endoscopic biliary endoprosthesis versus duct clearance for bile duct stones in high-risk patients. Lancet, 348, 791-3.

Choudhary, A., Bechtold, M. L., Arif, M., Szary, N. M., Puli, S. R., Othman, M. O., Pais, W. P., Antillon, M. R. \& Roy, P. K. (2011). Pancreatic stents for prophylaxis against post-ERCP pancreatitis: a meta-analysis and systematic review. Gastrointest Endosc, 73, 275-82.

Chung, M. G., Kang, D. H., Park, D. K., Park, J. J., Park, H. C. \& Kim, J. H.(2001). Successful treatment of Boerhaave's syndrome with endoscopic insertion of a self-expandable metallic stent: report of three cases and a review of the literature. Endoscopy, 33, 894-7.

Cicek, B., Parlak, E., Oguz, D., Disibeyaz, S., Koksal, A. S. \& Sahin, B. (2006). Endoscopic treatment of pancreatic fistulas. Surg Endosc, 20, 1706-12.

Conio, M., Repici, A., Battaglia, G., De Pretis, G., Ghezzo, L., Bittinger, M., Messmann, H., Demarquay, J. F., Blanchi, S., Togni, M., Conigliaro, R. \& Filiberti, R. (2007). A randomized prospective comparison of self-expandable plastic stents and partially covered self-expandable metal stents in the palliation of malignant esophageal dysphagia. Am J Gastroenterol, 102, 2667-77.

Davids, P. H. P., Groen, A. K., Rauws, E. A. J., Tytgat, G. N. \& Huibregtse, K. (1992). Randomized trial of self-expanding metal stents versus polyethylene stents for distal malignant biliary obstruction. Lancet, 340, 1488-92.

De Palma, G. D., di Matteo, E., Romano, G., Fimmano, A., Rondinone, G. \& Catanzano, C. (1996). Plastic prosthesis versus expandable metal stents for palliation of inoperable esophageal thoracic carcinoma: a controlled prospective study. Gastrointest Endosc, $43,478-82$.

De Palma, G. D., Galloro, G., Siciliano, S., Iovino, P. \& Catanzano, C. (2001). Unilateral versus bilateral endoscopic hepatic duct drainage in patients with malignant hilar biliary obstruction: results of a prospective, randomized, and controlled study. Gastrointest Endosc, 53, 547-53.

De Palma, G. D., Galloro, G., Romano, G., Sottile, R., Puzziello, A., Persico, F., Masone, S., Labianca, O. \& Persico, G. (2003). Long-term follow-up after endoscopic biliary stent placement for bile duct strictures from laparoscopic cholecystectomy. Hepatogastroenterology, 50, 1229-31. 
Diamantis, G., Scarpa, M., Bocus, P., Realdon, S., Castoro, C., Ancona, E. \& Battaglia, G. (2011). Quality of life in patients with esophageal stenting for the palliation of malignant dysphagia. World J Gastroenterol, 17, 144-50.

Donelli, G., Guaglianone, E., Di Rosa, R., Fiocca, F. \& Basoli, A. (2007). Plastic biliary stent occlusion: factors involved and possible preventive approaches. Clin Med Res, 5, $53-$ 60.

Dumonceau, J. M., Cremer, M., Lalmand, B. \& Devière, J. (1999). Esophageal fistula sealing: choice of stent, practical management, and cost. Gastrointest Endosc, 49, 70-8.

Eickhoff, A., Knoll, M., Jakobs, R., Weickert, U., Hartmann, D., Schilling, D., Eickhoff, J. C. \& Riemann, J. F. (2005). Self-expanding metal stents versus plastic prostheses in the palliation of malignant dysphagia: long-term outcome of 153 consecutive patients. $J$ Clin Gastroenterol, 39, 877-85.

Eubanks, P. J., Hu, E., Nguyen, D., Procaccino, F., Eysselein, V. E. \& Klein, S. R. (1999). Case of Boerhaave's syndrome successfully treated with a self-expandable metallic stent. Gastrointest Endosc, 49, 780-3.

Fiori, E., Lamazza, A., De Cesare, A., Bononi, M., Volpino, P., Schillaci, A., Cavallaro, A. \& Cangemi, V. (2004). Palliative management of malignant rectosigmoidal obstruction. Colostomy vs. endoscopic stenting. A randomized prospective trial. Anticancer Res, 24, 265-8.

Fiorini, A., Fleischer, D., Valero, J., Israeli, E., Wengrower, D. \& Goldin, E. (2000). Selfexpandable metal coil stents in the treatment of benign esophageal strictures refractory to conventional therapy: a case series. Gastrointest Endosc, 52, 259-62.

Fischer, A., Thomusch, O., Benz, S., von Dobschuetz, E., Baier, P., Hopt, U. T. (2006). Nonoperative treatment of 15 benign esophageal perforations with self-expandable covered metal stents. Ann Thorac Surg, 81, 467-72.

Freeman, M. L., Nelson, D. B., Sherman, S., Haber, G. B., Herman, M. E., Dorsher, P. J., Moore, J. P., Fennerty, M. B., Ryan, M. E., Shaw, M. J., Lande, J. D. \& Pheley, A. M. (1996). Complications of endoscopic biliary sphincterotomy. N Engl J Med, 335, 90918.

Gaidos, J. K. \& Draganov, P. V. (2009). Treatment of malignant gastric outlet obstruction with endoscopically placed self-expandable metal stents. World J Gastroenterol, 15, 4365-4371.

Galandi, D., Schwarzer, G., Bassler, D. \& Allgaier, H. P. (2002). Ursodeoxycholic acid and/or antibiotics for prevention of biliary stent occlusion. Cochrane Database of Systematic Reviews, 3, (2002), CD003043.

Gevers, A. M., Macken, E., Hiele, M. \& Rutgeerts, P. (1998). A comparison of laser therapy, plastic stents, and expandable metal stents for palliation of malignant dysphagia in patients without a fistula. Gastrointest Endosc, 84, 383-8.

Grönroos, J. M., Gullichsen, R., Laine, S. \& Salminen, P. (2010). Endoscopic palliation of malignant obstructive jaundice in extremely elderly patients: plastic stent is enough. Minim Invasive Ther Allied Technol, 19, 122-4.

Homs, M. Y., Steyerberg, E. W., Eijkenboom, W. M., Tilanus, H. W., Stalpers, L. J., Bartelsman, J. F., van Lanschot, J. J, Wijrdeman, H. K., Mulder, C. J., Reinders, J. G., Boot, H., Aleman, B. M., Kuipers, E. J. \& Siersema, P. D. (2004). Single-dose brachytherapy versus metal stent placement for the palliation of dysphagia from oesophageal cancer: multicentre randomised trial. Lancet, 364, 1497-504.

Horiuchi, A., Nakayama, Y., Kajiyama, M., Kato, N., Kamijima, T., Graham, D. Y. \& Tanaka, N. (2010). Biliary stenting in the management of large or multiple common bile duct stones. Gastrointest Endosc, 71, 1200-1203. 
Hu, B., Wang, T.,T., Shi, Z. M., Wang, S. Z., Lu, R., Pan, Y. M., Huang, H. \& Wang, S.P.(2011). A novel antireflux metal stent for the palliation of biliary malignancies: a pilot feasibility study (with video). Gastrointest Endosc, 73, 143-8.

Hubmann, R., Bodlaj, G., Czompo, M., Benkö, L., Pichler, P., Al-Kathib, S., Kiblböck, P., Shamyieh, A. \& Biesenbach, G. (2006). The use of self-expanding metal stents to treat acute esophageal variceal bleeding. Endoscopy, 38, 896-901.

Jeurnink, S. M., Steyerberg, E. W., van Hooft, J. E., van Eijck, C. H., Schwartz, M. P., Vleggaar, F. P., Kuipers, E. J. \& Siersema, P. D for the Dutch SUSTENT Study Group. (2010). Surgical gastrojejunostomy or endoscopic stent placement for the palliation of malignant gastric outlet obstruction (SUSTENT study): a multicenter randomized trial. Gastrointest Endosc, 71, 490-9.

Johnsson, E., Thune, A. \& Liedman, B. (2004). Palliation of malignant gastroduodenal obstruction with open surgical bypass or endoscopic stenting: clinical outcome and health economic evaluation. World J Surg, 28, 812-7.

Johnsson, E., Lundell, L. \& Liedman, B. (2005). Sealing of esophageal perforation or ruptures with expandable metallic stents: a prospective controlled study on treatment efficacy and limitations. Dis Esophagus, 18, 262-6.

Kaw, M., Singh, S. \& Gagneja, H. (2003). Clinical outcome of simultaneous self-expandable metal stents for palliation of malignant biliary and duodenal obstruction. Surg Endosc, 17, 457-61.

Keeling, W. B., Miller, D. L., Lam, G. T., Kilgo, P., Miller, J. I., Mansour, K. A. \& Force, S. D. (2010). Low mortality after treatment for esophageal perforation: a single-center experience. Ann Thorac Surg, 90, 1669-73.

Khot, U. P., Lang, A. W., Murali, K. \& Parker, M. C. (2002). Systematic review of the efficacy and safety of colorectal stents, Br J Surg, 89, 1096-102.

Kiernan, P. D., Khandhar, S. J., Fortes, D. L., Sheridan, M. J. \& Hetrick, V. (2010) Thoracic esophageal perforations. Am Surg, 76, 1355-62.

Kim, J. H., Song, H. Y., Shin, J. H., Choi, E., Kim, T. W., Jung, H. Y., Lee, G. H., Lee, S. K., Kim, M. H., Ryu, M. H., Kang, Y. K., Kim, B. S. \& Yook, J. H. (2007). Metallic stent placement in the palliative treatment of malignant gastroduodenal obstructions: prospective evaluation of results and factors influencing outcome in 213 patients. Gastrointest Endosc, 66, 256-64.

Knyrim, K., Wagner, H. J., Bethge, N., Keymling, M. \& Vakil, N. (1993). A controlled trial of an expansile metal stent for palliation of esophageal obstruction due to inoperable cancer. N Engl J Med, 329, 1302-7.

Königsrainer, A., Riedmann, B., De Vries, A., Ofner, D., Spechtenhauser, B., Aigner, F., Fritsch, E. \& Margreiter, R. (2000). Expandable metal stents versus laser combined with radiotherapy for palliation of unresectable esophageal cancer: a prospective randomized trial. Hepatogastroenterology, 47, 724-7.

Kozarek, R. A., Ball, T. J., Brandabur, J. J., Patterson, D. J., Low, D., Hill, L. \& Raltz, S. (1996). Expandable versus conventional esophageal prostheses: easier insertion may not preclude subsequent stent-related problems. Gastrointest Endosc, 43, 204-8.

Lau, W. Y., Lai, E. C. \& Lau, S. H. (2010). Management of bile duct injury after laparoscopic cholecystectomy: a review. ANZ J Surg, 80, 75-81.

Lee, H. J., Hong, S. P., Cheon, J. H., Kim, T. I., Min, B. S., Kim, N. K. \& Kim, W. H. (2011). Long-term outcome of palliative therapy for malignant colorectal obstruction in patients with unresectable metastatic colorectal cancers: endoscopic stenting versus surgery. Gastrointest Endosc, 73, 535-42. 
Low, D. E. \& Kozarek, R. A. (1998). Comparison of conventional and wire mesh expandable prostheses and surgical bypass in patients with malignant esophagorespiratory fistulas. Ann Thorac Surg, 65, 919-23.

Lowe, A. S., Beckett, C. G., Jowett, S., May, J., Stephenson, S., Scally, A., Tam, E. \& Kay, C. L. (2007). Self-expandable metal stent placement for the palliation of malignant gastroduodenal obstruction: experience in a large, single, UK centre. Clin Radiol, 62, 738-44.

Ly, J., O'Grady, G., Mittal, A., Plank, L. \& Windsor, J. A. (2010). A systematic review of methods to palliate malignant gastric outlet obstruction. Surg Endosc, 24, 290-7.

Maetani, I., Tada, T., Ukita, T., Inoue, H., Sakai, Y. \& Nagao, J. (2004). Comparison of duodenal stent placement with surgical gastrojejunostomy for palliation in patients with duodenal obstructions caused by pancreaticobiliary malignancies. Endoscopy, 36, 73-8.

Mainar, A., De Gregorio Ariza, M. A., Tejero, E., Tobío, R., Alfonso, E., Pinto, I., Herrera, M. \& Fernández, J. A. (1996). Acute colorectal obstruction: treatment with selfexpandable metallic stents before scheduled surgery--results of a multicenter study, Radiology, 210, 65-9.

Martin , D. F. \& Laasch, H. U. (2004). Gastroduodenal stenting. Semin Intervent Radiol, 21, 167-79.

Martinez-Santos, C., Lobato, R. F., Fradejas, J. M., Pinto, I., Ortega-Deballón, P. \& MorenoAzcoita, M. (2002). Self-expandable stent before elective surgery vs. emergency surgery for the treatment of malignant colorectal obstructions: comparison of primary anastomosis and morbidity rates, Dis Colon Rectum, 45, 401-6.

Maxton, D. G., Tweedle, D. E. \& Martin, D. F. (1995). Retained common bile duct stones after endoscopic sphincterotomy: temporary and longterm treatment with biliary stenting. Gut, 36, 446-9.

May, A., Hahn, E. G. \& Ell, C. (1996). Self-expanding metal stents for palliation of malignant obstruction in the upper gastrointestinal tract. Comparative assessment of three stent types implemented in 96 implantations. J Clin Gastroenterol, 22, 261-6.

May, A. \& Ell, C. (1998). Palliative treatment of malignant esophagorespiratory fistulas with Gianturco-Z stents. A prospective clinical trial and review of the literature on covered metal stents. Am J Gastroenterol, 93, 532-5.

McLoughlin, M.T., \& Byrne, M.F. (2008). Endoscopic stenting: where are we now and where can we go?, World J of Gastroenterol, 14, 3798-803.

Moss, A. C., Morris, E. \& Mac Mathuna, P. (2006). Palliative biliary stents for obstructing pancreatic carcinoma. Cochrane Database Systematic Reviews, 19, 2, (April 2006), CD004200.

Moss, A. C., Morris, E., Leyden, J. \& MacMathuna, P. (2007). Malignant distal biliary obstruction: a systematic review and meta-analysis of endoscopic and surgical bypass results. Cancer Treat Rev, 33, 213-21

Mutignani, M., Tringali, A., Shah, S. G., Perri, V., Familiari, P., Iacopini, F., Spada, C. \& Costamagna, G. (2007). Combined endoscopic stent insertion in malignant biliary and duodenal obstruction. Endoscopy, 39, 440-7.

Nguyen-Tang, T. \& Dumonceau, J. M. (2010). Endoscopic treatment in chronic pancreatitis, timing, duration and type of intervention. Best Pract Res Clin Gastroenterol, 24, 28198.

Paik,W. H., Park, Y. S., Hwang, J. H., Lee, S. H., Yoon, C. J., Kang, S. G., Lee, J. K., Ryu, J. K., Kim, Y. T. \& Yoon, Y. B. (2009). Palliative treatment with self-expandable metallic 
stents in patients with advanced type III or IV hilar cholangiocarcinoma: a percutaneous versus endoscopic approach. Gastrointest Endosc, 69, 55-62.

Park, S. Y., Park, C. H., Cho, S. B., Yoon, K. W., Lee, W. S., Kim, H. S., Choi, S.K. \& Rew, J. S. (2008). The safety and effectiveness of endoscopic biliary decompression by plastic stent placement in acute suppurative cholangitis compared with nasobiliary drainage. Gastrointest Endosc, 68, 1076-80.

Perdue, D. G., Freeman, M. L., DiSario, J. A., Nelson, D. B., Fennerty, M. B., Lee, J. G., Overby, C. S., Ryan, M. E., Bochna, G. S., Snady, H. W. \& Moore, J. P. (2008). Plastic versus self-expanding metallic stents for malignant hilar biliary obstruction: a prospective multicenter observational cohort study. J Clin Gastroenterol, 42, 1040-6.

Polydorou, A. A., Chisholm, E. M., Romanos, A. A., Dowsett, J. F., Cotton, P. B., Hatfield, A. R. \& Russell, R. C. (1989). A comparison of right versus left hepatic duct endoprosthesis insertion in malignant hilar biliary obstruction. Endoscopy, 21, 26671.

Repici, A., Vleggaar, F. P., Hassan, C., van Boeckel, P. G., Romeo, F., Pagano, N., Malesci, A. \& Siersema, P. D. (2010). Efficacy and safety of biodegradable stents for refractory benign esophageal strictures: the BEST (Biodegradable Esophageal Stent) study. Gastrointest Endosc, 72, 927-34.

Roseveare, C. D., Patel, P., Simmonds, N., Goggin, P. M., Kimble, J. \& Shepherd, H. A. (1998). Metal stents improve dysphagia, nutrition and survival in malignant oesophageal stenosis: a randomized controlled trial comparing modified Gianturco Z-stents with plastic Atkinson tubes. Eur J Gastroenterol Hepatol, 10, 653-7.

Ross, W. A., Alkassab, F., Lynch, P. M., Ayers, G. D., Ajani, J., Lee, J. H. \& Bismar, M. (2007). Evolving role of self-expanding metal stents in the treatment of malignant dysphagia and fistulas. Gastrointest Endosc, 65, 70-6.

Sabharwal, T., Hamady, M. S., Chui, S., Atkinson, S., Mason, R. \& Adam, A. (2003). A randomised prospective comparison of the Flamingo Wallstent and Ultraflex stent for palliation of dysphagia associated with lower third oesophageal carcinoma. Gut, 52, 922-6.

Saito, Y., Tanaka, T., Andoh, A., Minematsu, H., Hata, K., Tsujikawa, T., Nitta, N., Murata, K. \& Fujiyama, Y. (2007). Usefulness of biodegradable stents constructed of poly-1lactic acid monofilaments in patients with benign esophageal stenosis. World $J$ Gastroenterol, 13, 3977-80.

Sandha, G. S. \& Marcon, N. E. (1999). Expandable metal stents for benign esophageal obstruction. Gastrointest Endosc Clin North Am, 9, 437-46.

Sandha, G. S., Bourke, M. J., Haber, G. B. \& Kortan, P. P. (2004). Endoscopic therapy for bile leak based on a new classification: results in 207 patients. Gastrointest Endosc, 60, 567-74.

Saranovic, D., Djuric-Stefanovic, A., Ivanovic, A., Masulovic, D. \& Pesko, P. (2005). Fluoroscopically guided insertion of self-expandable metal esophageal stents for palliative treatment of patients with malignant stenosis of esophagus and cardia: comparison of uncovered and covered stent types. Dis Esophagus, 18, 230-8.

Schilling, D., Rink, G., Arnold, J. C., Benz, C., Adamek, H. E., Jakobs, R. \& Riemann, J. F. (2003). Prospective, randomized, single-center trial comparing 3 different $10 \mathrm{~F}$ plastic stents in malignant mid and distal bile duct strictures. Gastrointest Endosc, $58,54-8$.

Sebastian, S., Johnston, S., Geoghegan, T., Torreggiani, W. \& Buckley, M. (2004). Pooled analysis of the efficacy and safety of self-expanding metal stenting in malignant colorectal obstruction, Am J Gastroenterol, 99, 2051-7. 
Seo, J. K., Ryu, J. K., Lee, S. H., Park, J. K., Yang, K. Y., Kim, Y. T., Yoon, Y. B., Lee, H. W., Yi, N. J. \& Suh, K. S. (2009). Endoscopic treatment for biliary stricture after adult living donor liver transplantation. Liver Transpl, 15, 4, 369-80.

Sharma, B. C., Kumar, R., Agarwal, N. \& Sarin, S. K. (2005). Endoscopic biliary drainage by nasobiliary drain or by stent placement in patients with acute cholangitis. Endoscopy, 37, 439-43.

Sharma, P. \& Kozarek, R. (2010). Role of esophageal stents in benign and malignant diseases. Am J Gastroenterol, 105, 258-73.

Shepherd, H. A., Royle, G., Ross, A. P., Diba, A., Arthur, M. \& Colin-Jones, D. (1988). Endoscopic biliary endoprosthesis in the palliation of malignant obstruction of the distal common bile duct: a randomized trial. Br J Surg, 75, 1166-8.

Shin, J. H., Song, H. Y., Ko, G. Y., Lim, J. O., Yoon, H. K. \& Sung, K.B. (2004) Esophagorespiratory fistula: long-term results of palliative treatment with covered expandable metallic stents in 61 patients. Radiology, 232, 252-9.

Siersema, P. D., Hop, W. C., van Blankenstein, M., van Tilburg, A. J., Bac, D. J., Homs, M. Y. \& Kuipers, E. J. (2001), A comparison of 3 types of covered metal stents for the palliation of patients with dysphagia caused by esophagogastric carcinoma: a prospective, randomized study. Gastrointest Endosc, 54, 145-53.

Siersema, P. D., Homs, M. Y., Haringsma, J., Tilanus, H. W. \& Kuipers, E. J. (2003). Use of large-diameter metallic stents to seal traumatic nonmalignant perforations of the esophagus. Gastrointest Endosc, 58, 356-61.

Smith, A. C., Dowsett, J. F., Russell, R. C., Hatfield, A. R. \& Cotton, P. B. (1994). Randomised trial of endoscopic stenting versus surgical bypass in malignant low bile duct obstruction. Lancet, 344, 1655-60.

Soehendra, N. \& Reynders-Frederix, V. (1980). Palliative bile duct drainage - a new endoscopic method of introducing a transpapillary drain. Endoscopy, 12, 8-11.

Tarnasky, P. R. (2003). Mechanical prevention of post-ERCP pancreatitis by pancreatic stents: results, techniques, and indications. JOP, 4, 58-67.

Tarniță, D., Tarniță, D. N., Bîzdoacă, N., Mîndrilă, I. \& Vasilescu, M. (2009). Properties and medical applications of shape memory alloys. Rom J Morphol Embryol, 50, 15-21.

Thomas, T., Abrams, K. R., Subramanian, V., Mannath, J. \& Ragunath, K. (2011) Esophageal stents for benign refractory strictures: a meta-analysis. Endoscopy, (in press).

Tilney, H. S., Lovegrove, R. E., Purkayastha, S., Sains, P. S., Weston-Petrides, G. K, Darzi, A. W., Tekkis, P. P. \& Heriot, A. G. (2007). Comparison of colonic stenting and open surgery for malignant large bowel obstruction, Surg Endosc, 21, 225-33.

Tzovaras, G., Peyser, P., Kow, L., Wilson, T., Padbury, R. \& Toouli, J. (2001). Minimally invasive management of bile leak after laparoscopic cholecystectomy. HPB (Oxford), 3, 165-8.

Vakil, N., Morris, A. I., Marcon, N., Segalin, A., Peracchia, A., Bethge, N., Zuccaro, G., Bosco, J. J. \& Jones, W.F. (2001). A prospective, randomized, controlled trial of covered expandable metal stents in the palliation of malignant esophageal obstruction at the gastroesophageal junction. Am J Gastroenterol, 96, 1791-6.

van der Gaag, N. A., Rauws, E. A., van Eijck, C. H., Bruno, M. J., van der Harst, E., Kubben, F. J., Gerritsen, J. J., Greve, J. W., Gerhards, M. F., de Hingh, I. H., Klinkenbijl, J. H., Nio, C. Y., de Castro, S. M., Busch, O. R., van Gulik, T. M., Bossuyt, P. M. \& Gouma, D. J. (2010). Preoperative biliary drainage for cancer of the head of the pancreas. $N$ Engl J Med, 362, 129-37. 
van Heel, N. C., Haringsma, J., Spaander, M. C., Bruno, M. J. \& Kuipers, E. J. (2010) Shortterm esophageal stenting in the management of benign perforations. Am J Gastroenterol, 105, 1515-20.

Van Steenbergen, W., Pelemans, W. \& Fevery, J. (1992). Endoscopic biliary endoprosthesis in elderly patients with large bile duct stones: long-term follow-up. J Am Geriatr Soc, 40, 57-60.

Verschuur, E. M., Repici, A., Kuipers, E. J., Steyerberg, E. W. \& Siersema, P. D. (2008). New design esophageal stents for the palliation of dysphagia from esophageal or gastric cardia cancer: a randomized trial. Am J Gastroenterol, 103, 304-12.

Vitale, G. C., Tran, T. C., Davis, B. R., Vitale, M., Vitale, D. \& Larson, G. (2008). Endoscopic management of postcholecystectomy bile duct strictures. J Am Coll Surg, 206, 91823.

Wadhwa, R. P., Kozarek, R. A., France, R. E., Brandabur, J. J., Gluck, M., Low, D. E., Traverso, L. W. \& Moonka, R. (2003). Use of self-expandable metallic stents in benign GI diseases. Gastrointest Endosc, 58, 207-12.

Weber, A., Schneider, J., Neu, B., Meining, A., Born, P., Schmid, R. M. \& Prinz, C. (2007). Endoscopic stent therapy for patients with chronic pancreatitis: results from a prospective follow-up study. Pancreas, 34, 287-94.

Weber, A., Mittermeyer, T., Wagenpfeil, S., Schmid, R. M. \& Prinz, C. (2009). Self-expanding metal stents versus polyethylene stents for palliative treatment in patients with advanced pancreatic cancer. Pancreas, 38, e7-e12.

Wilcox, C. M. \& Varadarajulu, S. (2006). Endoscopic therapy for chronic pancreatitis: an evidence-based review. Curr Gastroenterol Rep, 8, 104-10.

Williams, E.D. \& Draganov, P.V. (2009). Endoscopic management of biliary strictures after liver transplantation. World J Gastroenterol, 15, 3725-33.

Williams, E. J., Green, J., Beckingham, I., Parks, R., Martin, D. \& Lombard, M. for the British Society of Gastroenterology. (2008). Guidelines on the management of common bile duct stones. Gut, 57, 1004-21.

Wright, G., Lewis, H., Hogan, B., Burroughs, A., Patch, D. \& O'Beirne, J. (2010). A selfexpanding metal stent for complicated variceal hemorrhage: experience at a single center. Gastrointest Endosc, 71, 71-8.

Xinopoulos, D., Dimitroulopoulos, D., Theodosopoulos, T., Tsamakidis, K., Bitsakou, G., Plataniotis, G., Gontikakis, M., Kontis, M., Paraskevas, I., Vassilobpoulos, P. \& Paraskevas, E. (2004). Stenting or stoma creation for patients with inoperable malignant colonic obstructions? Results of a study and cost-effectiveness analysis. Surg Endosc, 18, 421-6.

Zehetner, J., Shamiyeh, A., Wayand, W. \& Hubmann, R. (2008). Results of a new method to stop acute bleeding from esophageal varices: implantation of a self-expanding stent. Surg Endosc, 22, 2149-52. 


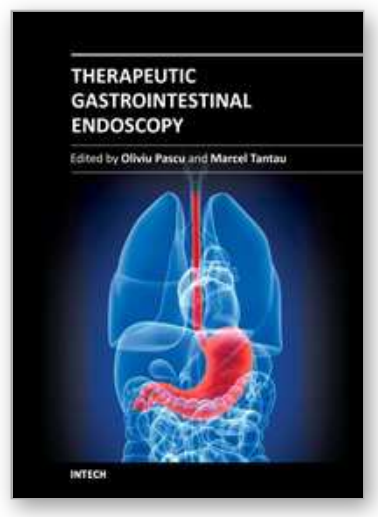

\author{
Therapeutic Gastrointestinal Endoscopy \\ Edited by Prof. Oliviu Pascu
}

ISBN 978-953-307-743-7

Hard cover, 216 pages

Publisher InTech

Published online 22, September, 2011

Published in print edition September, 2011

Endoscopy has had a big role in the development of modern gastroenterology. Modern endoscopy will certainly be more therapeutic. It started with endoscopic hemostasis and polipectomy, than beginning of the 1970 's with the advent of endoscopic sphincterotomy extended to biliopancreatic pathology and has a huge impact in this difficult pathology. Plastic stents made the first steps in endoscopic palliation of neoplastic jaundice, metallic stents, covered or uncovered are better for biliary palliation and can be used also for palliation neoplastic obstruction at different levels of the digestive tube. Resection of digestive tumors has evolved now to sub-mucosal resection, looking to have one-piece complete resection. Interventional endoscopy is now very complex and takes a lot of time for endoscopists to learn properly these techniques. This book is a very good up-to-date overview of new techniques of interventional endoscopy for those who want to learn or develop their knowledges in this field.

\title{
How to reference
}

In order to correctly reference this scholarly work, feel free to copy and paste the following:

Michael Pavlides and David A Gorard (2011). Stents in Gastrointestinal Endoscopy, Therapeutic Gastrointestinal Endoscopy, Prof. Oliviu Pascu (Ed.), ISBN: 978-953-307-743-7, InTech, Available from: http://www.intechopen.com/books/therapeutic-gastrointestinal-endoscopy/stents-in-gastrointestinalendoscopy 1

\section{INTECH}

open science | open minds

\section{InTech Europe}

University Campus STeP Ri

Slavka Krautzeka 83/A

51000 Rijeka, Croatia

Phone: +385 (51) 770447

Fax: +385 (51) 686166

www.intechopen.com

\section{InTech China}

Unit 405, Office Block, Hotel Equatorial Shanghai

No.65, Yan An Road (West), Shanghai, 200040, China 中国上海市延安西路65号上海国际贵都大饭店办公楼 405 单元

Phone: +86-21-62489820

Fax: $+86-21-62489821$ 
(C) 2011 The Author(s). Licensee IntechOpen. This chapter is distributed under the terms of the Creative Commons Attribution-NonCommercialShareAlike-3.0 License, which permits use, distribution and reproduction for non-commercial purposes, provided the original is properly cited and derivative works building on this content are distributed under the same license. 